Research Article

\title{
Kinetic Modeling Study of the Industrial Sulfur Recovery Process for Operating Condition Optimization
}

\author{
Shan Huang $\mathbb{D}^{1},{ }^{1}$ Zhaohui Teng, ${ }^{1}$ Lisheng Zhang, ${ }^{2}$ Qulan Zhou $\mathbb{D}^{1},{ }^{1}$ and $\mathrm{Na} \mathrm{Li}^{1}$ \\ ${ }^{1}$ State Key Laboratory of Multiphase Flow in Power Engineering, Xi'an Jiaotong University, Xi'an 710049, China \\ ${ }^{2}$ Natural Gas Purification Plant of Puguang Gasfield, Dazhou 636150, China \\ Correspondence should be addressed to Qulan Zhou; qlzhou@mail.xjtu.edu.cn
}

Received 20 March 2020; Accepted 12 May 2020; Published 25 May 2020

Guest Editor: Norbert Miskolczi

Copyright (c) 2020 Shan Huang et al. This is an open access article distributed under the Creative Commons Attribution License, which permits unrestricted use, distribution, and reproduction in any medium, provided the original work is properly cited.

\begin{abstract}
Sulfur recovery from acid gas $\left(\mathrm{H}_{2} \mathrm{~S}\right.$ and $\left.\mathrm{CO}_{2}\right)$, which is contained in fresh natural gas, can bring many economic and environmental benefits, and this topic has been studied for years. Finding an optimal operating condition for the factory is of much importance. In this paper, we built a reactor network analysis model with a detailed mechanism to describe and calculate the process in the sulfur recovery unit. This detailed mechanism included 94 species and 615 elementary reactions. Our model has a more accurate residence time than other existing models. This simulation model was verified with industrial data, and the calculation result was highly consistent with the industrial data and more accurate than other approaches. Then, we used this reactor network analysis model to study the effect of the excess air coefficient, the thermal reactor temperature, and the temperature of cooling water on the sulfur recovery efficiency of a real device in the Puguang gas field. The result showed the excess air coefficient and thermal reactor temperature had a clear impact on sulfur recovery efficiency. After analysis, we got the optimum condition parameters for this device. At last, these parameters were tested in the real sulfur recovery device, and the result was reasonable. Our research provides a way to improve the sulfur recovery process in the industry, and it can be helpful to reduce pollution emissions and improve economic performance.
\end{abstract}

\section{Introduction}

Sulfur recovery in natural gas extraction has been the subject of much research in the recent years. The Claus process is widely used to recover elementary sulfur from acid gas contained in fresh natural gas. [1] And, the gas from the sour water stripper (SWS) is also a common fuel used in Claus process. It involves thermal oxidation of hydrogen sulfide and its reaction with sulfur dioxide to form sulfur and water vapor.

The basic scheme of a sulfur recovery unit (SRU) is shown in Figure 1. [2] There are five main kinds of devices in the scheme: a burner, a thermal reactor (TR), a waste heat boiler (WHB), two Claus reactors (CR), and a series of sulfur condensers. The acid gas (containing $\mathrm{H}_{2} \mathrm{~S}, \mathrm{CO}_{2}, \mathrm{H}_{2} \mathrm{O}, \mathrm{CO}$, $\mathrm{NH}_{3}$, and so on) is mixed with air at the burner [3], and then the gas burns and flows into the thermal reactor, which provides necessary residence time to form the Claus gas $\left(\mathrm{H}_{2} \mathrm{~S}: \mathrm{SO}_{2}=2\right)$. Next, Claus gas goes into the waste heat boiler and the first condenser to cool down, and after that the Claus gas is sent into the Claus reactors.

The two steps of the overall process may be represented as follows. Equation (1) is the overall reaction occurring in the TR. In this process, a third of the total $\mathrm{H}_{2} \mathrm{~S}$ reacts with oxygen at the best stoichiometric ratio to form Claus gas. The main component of Claus gas is the residual $\mathrm{H}_{2} \mathrm{~S}$ and the generated $\mathrm{SO}_{2}$ (the molar concentration ratio of $\mathrm{H}_{2} \mathrm{~S}$ and $\mathrm{SO}_{2}$ is about 2, which meets the best stoichiometric ratio of equation (2). Equation (2) takes place in the downstream Claus reactor, and the residual $\mathrm{H}_{2} \mathrm{~S}$ is oxidized by the generated $\mathrm{SO}_{2}$ to form $\mathrm{S}_{x}$. The elemental sulfur is removed by condensation in the three-level condensers: 


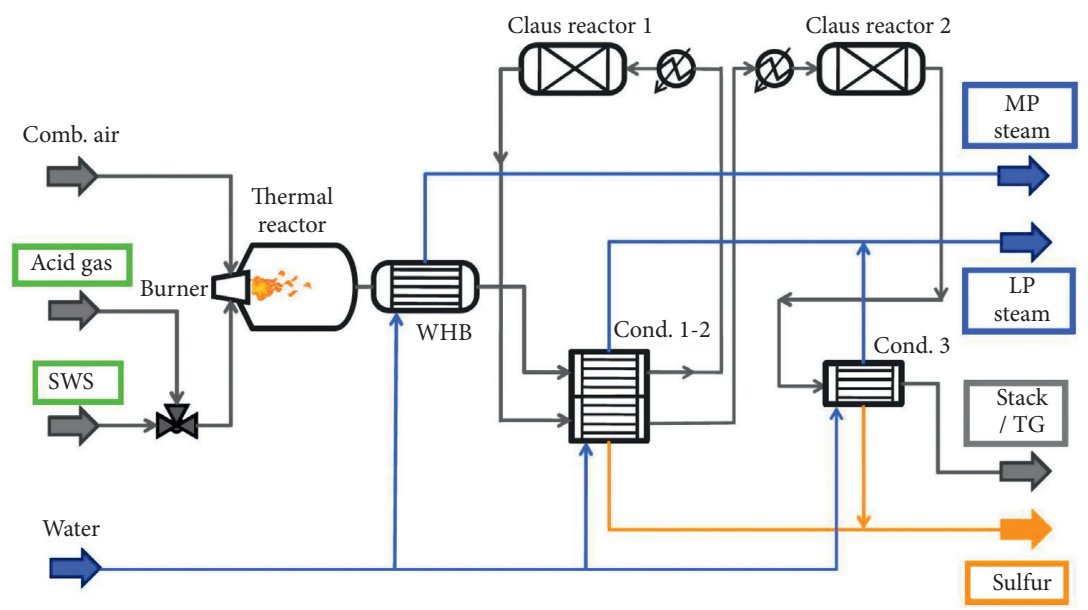

Figure 1: Basic scheme of a sulfur recovery unit.

$$
\begin{array}{r}
\mathrm{H}_{2} \mathrm{~S}+\frac{3}{2} \mathrm{O}_{2} \longrightarrow \mathrm{SO}_{2}+\mathrm{H}_{2} \mathrm{O} \\
2 \mathrm{H}_{2} \mathrm{~S}+\mathrm{SO}_{2} \longrightarrow \frac{3}{2} \mathrm{~S}_{2}+2 \mathrm{H}_{2} \mathrm{O}
\end{array}
$$

The most efficient and economical way to find the bestoperating conditions for an industrial sulfur recovery process is simulation calculation. In 2015, Nabikandi and Fatemi [4] performed a simulation of an industrial Claus SRU process with equilibrium and kinetic methods comparatively. Their research revealed that both kinetic and equilibrium models present reliable results, but the kinetic model which has the ability of prediction compositions, temperature, and pressure along the furnace showed higher potential to cover the industrial results. But, the reaction mechanism in this process is rather complex and has not been completely understood. With the development of the reaction mechanism and the tuning of the kinetic parameters, the kinetic simulation methods can get closer to the real results. After reviewing the kinetic models of $\mathrm{H}_{2} \mathrm{~S}$ combustion and evaluating the effect of the acid gas impurities, Gupta et al. [5] indicated that a comprehensive kinetic model that can capture the combustion chemistry of $\mathrm{H}_{2} \mathrm{~S}$ along with the presence of impurities in Claus reactors can improve the efficiency of sulfur recovery processes and sulfur quality. And, the effect of impurities such as aromatics and mercaptans on the Claus process was studied by Ibrahim [6] and Mahdipoor [7], respectively.

Though many industrial simulation studies have been conducted, there is still room for improvement. The authors in $[8,9]$ built a detailed reaction mechanism of the acid gas, and they used this mechanism to do a CFD simulation of the reactor furnace of the sulfur recovery units which focused on the flow fields of the process. Then, the authors in $[3,10]$ also did a kinetic simulation of acid gas destruction with a detailed mechanism for simultaneous syngas and sulfur recovery, and their work investigated the optimal operating conditions for $\mathrm{H}_{2}$ production other than sulfur recovery. Manenti et al. [11-15] did much work on the modeling simulation of the sulfur recovery process, and their work covered not only the revision of the combustion mechanism but also the optimization of the operating conditions for sulfur recovery. Though their work was valuable, the mechanism and model used in their work did not update with the recent research findings. Most of all, their optimization results were not verified by the industrial data.

To find a practical way to improve the efficiency of the industrial sulfur recovery process, this paper was trying to find the optimum operating condition for the sulfur recovery unit, especially for the burner, TR, and WHB. To achieve this, we built a new reactor network analysis (RNA) model with a revised detailed mechanism for the first step. Then, the new analysis model with the revised mechanism was verified with industrial data and other simulation results. After verification, this analysis scheme was used to do the condition optimization research of a real sulfur recovery unit in the Puguang Gas Field in China, and then the calculation result was tested in the factory to see if the optimum parameters work well.

The organization of the paper is as follows. In Section 2, we discuss the development of the reaction mechanism. In Section 3, the settings of the RNA model and the verification of this model are displayed. The operating condition optimization research is provided in Section 4. At last, we made a conclusion of this research in Section 5. The results of this research will provide further data to improve the process of elementary sulfur recovery in the industry, which can be helpful to reduce pollution emissions and improve economic performance.

\section{Reaction Mechanism}

In our study, we summarized and discussed the recent development of elementary reaction studies at first, and then we selected appropriate reactions to fulfill the reaction mechanism. And, some parameters of certain elementary reactions have been revised according to the new academic results. The final mechanism includes 94 species and 615 elementary reactions. 
2.1. $\mathrm{H}_{2} \mathrm{~S}$ Pyrolysis. $\mathrm{H}_{2} \mathrm{~S}$ pyrolysis plays a key role in the combustion process; not only because $\mathrm{H}_{2} \mathrm{~S}$ is the source of the sulfur in SRUs, but also $\mathrm{H}_{2} \mathrm{~S}$ pyrolysis provides the radical pool, especially in the lean air combustion conditions. In 2003, Binoist et al. [16] did a kinetic study of the pyrolysis of $\mathrm{H}_{2} \mathrm{~S}$ at different residence times $(0.4 \sim 1.6 \mathrm{~s})$ and at different temperatures $\left(800 \sim 1100^{\circ} \mathrm{C}\right)$ by experiment and simulation. A detailed radical mechanism was written to account for the experimental results, and it was in good agreement with the experimental data. According to Binoist et al, the pyrolysis kinetic scheme was the first step and the core of a complete detailed mechanism capable of modeling the various oxidation reactions encountered in an industrial Claus furnace. In 2013, Manenti et al. [2] put forward a revised detailed kinetic scheme for the pyrolysis and oxidation of sulfur compounds. In their research, some adjustments were done to the pyrolysis of $\mathrm{H}_{2} \mathrm{~S}$. According to Manenti et al, the kinetic model accuracy was improved by $10-20 \%$, depending on the operating temperature. In 2017, Li et al. [17] presented a detailed kinetic mechanism for describing the chemical process during decomposition of the $\mathrm{H}_{2} \mathrm{~S}-\mathrm{CH}_{4}$ mixture under dilution condition, and the prediction of the conversion of $\mathrm{H}_{2} \mathrm{~S}$ was accurate. The kinetic parameters for the pyrolysis of $\mathrm{H}_{2} \mathrm{~S}$ are shown in Table 1 .

2.2. $\mathrm{H}_{2} \mathrm{~S}$ Oxidation. In 2013, Zhou et al. [18] studied the oxidation of $\mathrm{H}_{2} \mathrm{~S}$ in an atmospheric pressure flow reactor at temperatures from 950 to $1150 \mathrm{~K}$, and a comprehensive chemical kinetic model for $\mathrm{H}_{2} \mathrm{~S}$ was developed. The $\mathrm{H}_{2} \mathrm{~S}$ oxidation mechanism developed by Zhou et al has been validated versus the experimental data of the diluted $\mathrm{H}_{2} \mathrm{~S}$ oxidation process. In 2019, $\mathrm{Li}$ et al. [19] explored the oxidation mechanisms of $\mathrm{H}_{2} \mathrm{~S}$ by oxygen on activated carbon, and $\mathrm{H}_{2} \mathrm{~S}$ adsorbed on activated carbon is oxidized by $\mathrm{O}_{2}$-producing elemental sulfur, which further oxidized to $\mathrm{SO}_{2}$. This $\mathrm{H}_{2} \mathrm{~S}$ oxidation compilation included $\mathrm{H}_{2}$ oxidation, $\mathrm{SO}$ and $\mathrm{SO}_{2}$ oxidation mechanism, $\mathrm{S} / \mathrm{H}$ reaction subset, and other significant updated kinetic parameters for the $\mathrm{H} / \mathrm{S} / \mathrm{O}$ system. The reaction path analysis is shown in Figure 2.

In 2016, Barba et al. [20] did an experimental and numerical analysis of the oxidative decomposition of $\mathrm{H}_{2} \mathrm{~S}$. In this work, a comprehensive chemical kinetic model for the oxidation of $\mathrm{H}_{2} \mathrm{~S}$ in a low-oxygen atmosphere was studied, by varying the $\mathrm{O}_{2} / \mathrm{H}_{2} \mathrm{~S}$ ratio $(0.2 \sim 0.35)$, residence time $(150 \sim 300 \mathrm{~ms})$, and process temperatures $\left(900-1100^{\circ} \mathrm{C}\right)$. The results showed a very good agreement with the experimental values at higher temperatures $\left(1100^{\circ} \mathrm{C}\right)$. Relevant reactions of the kinetic scheme are shown in Table 2.

\subsection{Other Mechanisms}

2.3.1. $\mathrm{C} / \mathrm{H} / \mathrm{O}$ Mechanism. The mechanism for $\mathrm{C} / \mathrm{H} / \mathrm{O}$ is taken from the well-known GRI-3.0. This mechanism has been validated by many researchers and experimental results. The data were cited from http://combustion.berkeley. edu/gri-mech/.
TABLE 1: The kinetic parameters for the pyrolysis of $\mathrm{H}_{2} \mathrm{~S}$.

\begin{tabular}{|c|c|c|c|}
\hline Reactions $^{\mathrm{a}}$ & $\begin{array}{c}A \\
\left(\mathrm{~cm}^{3} \cdot \mathrm{mol}^{-1} \cdot \mathrm{s}^{-1}\right)\end{array}$ & $n$ & $E\left(\mathrm{cal} \cdot \mathrm{mol}^{-1}\right)$ \\
\hline $\mathrm{S}+\mathrm{H}+\mathrm{M}=\mathrm{SH}+\mathrm{M}$ & $0.62 \times 10^{17}$ & -0.6 & 0 \\
\hline $\mathrm{S}+\mathrm{H}_{2}=\mathrm{SH}+\mathrm{H}$ & $0.14 \times 10^{15}$ & 0.0 & 19300 \\
\hline $\mathrm{S}_{2}+\mathrm{M}=\mathrm{S}+\mathrm{S}+\mathrm{M}$ & $0.48 \times 10^{14}$ & 0.0 & 77000 \\
\hline $\mathrm{H}+\mathrm{S}_{2}+\mathrm{M}=\mathrm{HS}_{2}+\mathrm{M}$ & $0.40 \times 10^{14}$ & 2.84 & 1665 \\
\hline $\mathrm{SH}+\mathrm{SH}=\mathrm{S}_{2}+\mathrm{H}_{2}$ & $0.50 \times 10^{12}$ & 0.0 & 0.0 \\
\hline $\mathrm{SH}+\mathrm{S}=\mathrm{S}_{2}+\mathrm{H}$ & $0.30 \times 10^{14}$ & 0.0 & 0.0 \\
\hline $\mathrm{H}_{2} \mathrm{~S}+\mathrm{M}=\mathrm{S}+\mathrm{H}_{2}+\mathrm{M}$ & $0.16 \times 10^{25}$ & 2.613 & 89100 \\
\hline $\mathrm{H}_{2} \mathrm{~S}+\mathrm{H}=\mathrm{SH}+\mathrm{H}_{2}$ & $0.35 \times 10^{08}$ & 1.94 & 904 \\
\hline $\mathrm{H}_{2} \mathrm{~S}+\mathrm{S}=\mathrm{SH}+\mathrm{SH}$ & $0.83 \times 10^{14}$ & 0.0 & 7400 \\
\hline $\mathrm{HS}_{2}+\mathrm{H}=\mathrm{SH}+\mathrm{SH}$ & $0.97 \times 10^{08}$ & 1.62 & -1030 \\
\hline Duplicate & $0.11 \times 10^{14}$ & 0.353 & 210 \\
\hline $\mathrm{HS}_{2}+\mathrm{H}=\mathrm{S}_{2}+\mathrm{H}_{2}$ & $0.12 \times 10^{09}$ & 1.653 & -1105 \\
\hline $\mathrm{HS}_{2}+\mathrm{H}=\mathrm{H}_{2} \mathrm{~S}+\mathrm{S}$ & $0.44 \times 10^{14}$ & 0.0 & 6326 \\
\hline $\mathrm{HS}_{2}+\mathrm{S}=\mathrm{S}_{2}+\mathrm{SH}$ & $0.42 \times 10^{07}$ & 2.2 & -600 \\
\hline $\mathrm{HS}_{2}+\mathrm{SH}=\mathrm{H}_{2} \mathrm{~S}+\mathrm{S}_{2}$ & $0.63 \times 10^{04}$ & 3.050 & -1105 \\
\hline $\mathrm{HS}_{2}+\mathrm{HS}_{2}=\mathrm{H}_{2} \mathrm{~S}_{2}+\mathrm{S}_{2}$ & $0.96 \times 10^{1}$ & 1.0 & 57030 \\
\hline $\mathrm{H}_{2} \mathrm{~S}_{2}+\mathrm{M}=\mathrm{SH}+\mathrm{SH}+\mathrm{M}$ & $0.14 \times 10^{16}$ & 0.0 & 15000 \\
\hline $\mathrm{H}_{2} \mathrm{~S}_{2}+\mathrm{H}=\mathrm{HS}_{2}+\mathrm{H}_{2}$ & $0.50 \times 10^{08}$ & 1.933 & -1408 \\
\hline $\mathrm{H}_{2} \mathrm{~S}_{2}+\mathrm{H}=\mathrm{H}_{2} \mathrm{~S}+\mathrm{SH}$ & $0.20 \times 10^{15}$ & 0.0 & 0.0 \\
\hline $\mathrm{H}_{2} \mathrm{~S}_{2}+\mathrm{S}=\mathrm{HS}_{2}+\mathrm{SH}$ & $0.29 \times 10^{07}$ & 2.31 & 1204 \\
\hline $\mathrm{H}_{2} \mathrm{~S}_{2}+\mathrm{SH}=\mathrm{HS}_{2}+\mathrm{H}_{2} \mathrm{~S}$ & $0.64 \times 10^{04}$ & 2.98 & -1480 \\
\hline
\end{tabular}

${ }^{a}$ Declared duplicate reaction.

2.3.2. Formation of Sulfur Vapor $\left(S_{2}\right)$. Thanks to the pyrolysis and oxidation of $\mathrm{H}_{2} \mathrm{~S}$, there will be an abundance of $\mathrm{S}$ radicals and HS radicals in the thermal reactor. And, elemental sulfur vapor $\left(S_{2}\right)$ can be formed via the following chemical reactions [21]:

$$
\begin{gathered}
\mathrm{SH}+\mathrm{SH} \longleftrightarrow \mathrm{S}_{2}+\mathrm{H}_{2} \\
\mathrm{M}+\mathrm{S}+\mathrm{S} \longleftrightarrow \mathrm{S}_{2}+\mathrm{M}
\end{gathered}
$$

And, equation (3) leads to the production of $\mathrm{H}_{2}$, and hydrogen is a species which deserved consideration in the Claus process. As seen in the literature, Cong et al. [8], Ravikumar et al. [10], Savelieva et al. [22], and Li et al. [23] have studied the way to increase hydrogen production via the thermolysis and oxidation of hydrogen sulfide $\left(\mathrm{H}_{2} \mathrm{~S}\right)$.

2.3.3. Molecular Growth of Sulfur. When the concentrations of S, HS, $\mathrm{S}_{2}, \mathrm{H}_{2} \mathrm{~S}_{2}$, and $\mathrm{HS}_{2}$ are relatively high, the chance of growth from $S$ to $S_{8}$ increases. The major steps can be presented as follows [24]:

$$
\begin{aligned}
& S_{2}+S+M \leftrightarrow S_{3}+M \\
& S_{3}+S+M \leftrightarrow S_{4}+M \\
& S_{4}+S+M \leftrightarrow S_{5}(c)+M \\
& S_{5}+S+M \leftrightarrow S_{6}(c)+M \\
& S_{6}+S+M \leftrightarrow S_{7}(c)+M \\
& S_{7}+S+M \leftrightarrow S_{8}(c)+M
\end{aligned}
$$

for thermodynamic reasons, the ring or the cyclic structure of $\mathrm{S}_{5}(\mathrm{c})$ would be formed. Depending on the temperature, an equilibrium would be formed between the open linear 


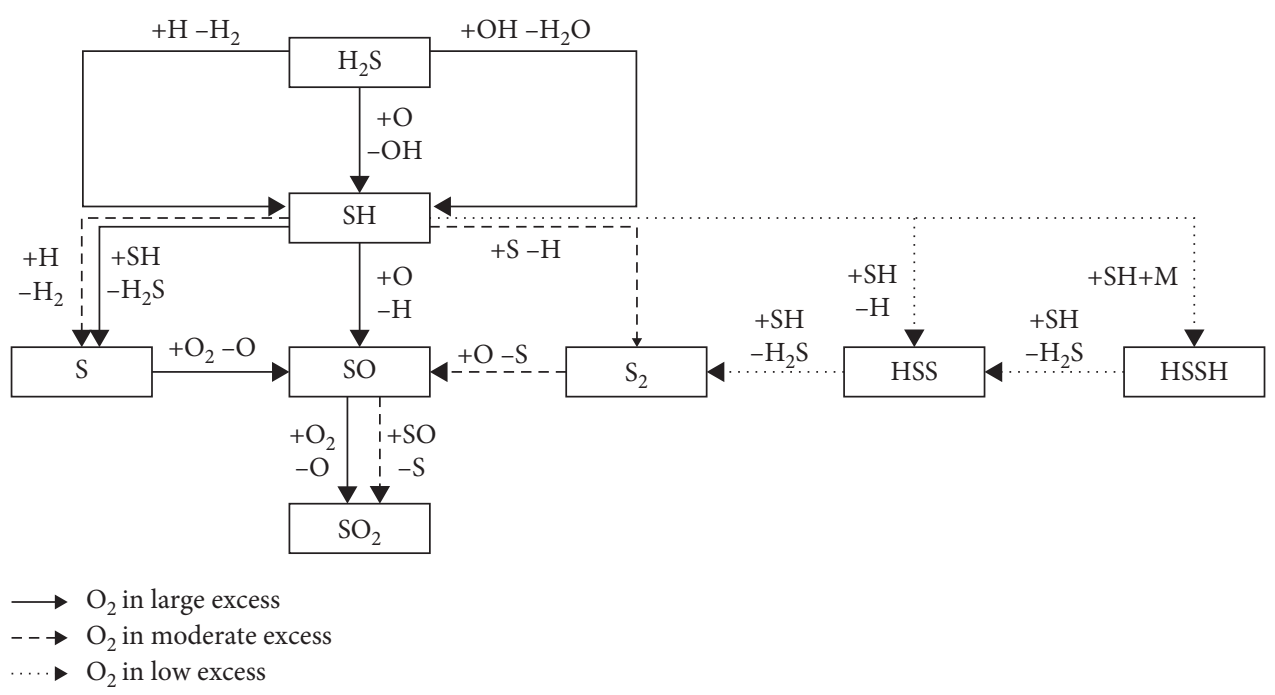

FIgURE 2: Schematic mechanism for fuel-lean $\mathrm{H}_{2} \mathrm{~S}$ oxidation showing main consumption pathways.

TABLE 2: Relevant reactions of the kinetic scheme.

\begin{tabular}{|c|c|c|c|}
\hline Reactions & $A\left(\mathrm{~cm}^{3} \cdot \mathrm{mol}^{-1} \cdot \mathrm{s}^{-1}\right)$ & $n$ & $E\left(\mathrm{cal} \cdot \mathrm{mol}^{-1}\right)$ \\
\hline $\mathrm{S}+\mathrm{O}_{2}=\mathrm{SO}+\mathrm{O}$ & $4.898558 \times 10^{05}$ & 2.11 & 1450.7 \\
\hline $\mathrm{SO}+\mathrm{O}_{2}=\mathrm{SO}_{2}+\mathrm{O}$ & $7.920000 \times 10^{06}$ & 1.416 & 3629.0 \\
\hline $\mathrm{H}_{2} \mathrm{O}_{2}+\mathrm{SH}=\mathrm{H}_{2} \mathrm{~S}+\mathrm{HO}_{2}$ & $5.570000 \times 10^{04}$ & 2.8 & 8668.0 \\
\hline $\mathrm{S}_{2}+\mathrm{O}=\mathrm{SO}+\mathrm{S}$ & $1.720945 \times 10^{11}$ & 0.7 & -231.0 \\
\hline $\mathrm{HS}_{2}+\mathrm{O}_{2}=\mathrm{HO}_{2}+\mathrm{S}_{2}$ & $4.100000 \times 10^{03}$ & 2.5 & 10585.0 \\
\hline $\mathrm{SH}+\mathrm{O}_{2}=\mathrm{H}+\mathrm{SO}_{2}$ & $6.500000 \times 10^{11}$ & 0.0 & 15000.0 \\
\hline $\mathrm{H}_{2} \mathrm{~S}+\mathrm{S}=2 \mathrm{SH}^{\mathrm{a}}$ & $8.870000 \times 10^{06}$ & 2.3 & 9007.0 \\
\hline $\mathrm{H}_{2} \mathrm{~S}+\mathrm{S}=2 \mathrm{SH}^{\mathrm{a}}$ & $9.181582 \times 10^{17}$ & -1.7 & 5975.0 \\
\hline $\mathrm{SH}+\mathrm{HO}_{2}=\mathrm{HSO}+\mathrm{OH}$ & $2.460000 \times 10^{08}$ & 1.5 & -2169.0 \\
\hline $\mathrm{SH}+\mathrm{O}_{2}=\mathrm{SO}+\mathrm{OH}$ & $7.500000 \times 10^{04}$ & 2.1 & 16384.0 \\
\hline $\mathrm{S}_{2} \mathrm{O}+\mathrm{SH}=\mathrm{HS}_{2}+\mathrm{SO}$ & $1.000000 \times 10^{13}$ & 0.0 & 8000.0 \\
\hline $\mathrm{SH}+\mathrm{O}_{2}=\mathrm{HSO}+\mathrm{O}$ & $2.290000 \times 10^{06}$ & 1.8 & 20008.0 \\
\hline $\mathrm{HS}_{2}+\mathrm{O}_{2}=\mathrm{HSO}+\mathrm{SO}$ & $6.610000 \times 10^{03}$ & 1.9 & 7071.0 \\
\hline
\end{tabular}

${ }^{\mathrm{a}}$ Declared duplicate reaction.

structure and its ring counterpart. [21] The process can be described as the following typical reaction:

$$
\mathrm{S}_{5}(\mathrm{c})+\mathrm{M} \leftrightarrow \mathrm{S}_{5}+\mathrm{M}
$$

And, radicals like $\mathrm{HS}, \mathrm{H}_{2} \mathrm{~S}_{2}$, and $\mathrm{HS}_{2}$ can also participate in the formation process of big molecules like $S_{3} \sim S_{8}$. Typical chemical processes are as follows:

$$
\begin{aligned}
\mathrm{S}_{2}+\mathrm{HS}_{2} \leftrightarrow \mathrm{S}_{4}+\mathrm{H} \\
\mathrm{HS}+\mathrm{S}_{7} \leftrightarrow \mathrm{S}_{8}(\mathrm{c})+\mathrm{H}
\end{aligned}
$$

2.3.4. Formation of COS and $\mathrm{CS}_{2}$. There is always $\mathrm{CO}_{2}$ in the sour gas, and its volume fraction can take up to $40 \%$. The carbon species can react with the sulfur species, and the typical products are carbonyl sulfide (COS) and carbon disulfide $\left(\mathrm{CS}_{2}\right)$. In SRUs, COS decreases the production of elemental sulfur and it is a problem for certain Claus catalysts. [13] The chemical paths leading to the formation of those two species involve radical-addition reactions, and the most common mechanism generating COS is as follows:

$$
\mathrm{M}+\mathrm{CO}+\mathrm{S} \leftrightarrow \mathrm{COS}+\mathrm{M}
$$

Researchers indicated that the formation of COS has much to do with the presence of CO and sulfur [25-27]. So, we can conclude that $\mathrm{CO}$ is the main precursor of COS concerning $\mathrm{CO}_{2}$. Furthermore, Manenti et al found that $\mathrm{CO}$ conversion to COS achieves the thermodynamic equilibrium around $1000^{\circ} \mathrm{C}$, which is approximately the typical operating temperature of the thermal reactor furnace where the formation of COS is maximum [13].

A mechanism for the formation of $\mathrm{CS}_{2}$ is given by Petherbridge et al. [28]. They presented a sequence of reactions leading to the formation of $\mathrm{CS}_{2}$ as follows:

$$
\begin{aligned}
\mathrm{SH}+\mathrm{CH}_{3} & \leftrightarrow \mathrm{CH}_{3} \mathrm{SH} \\
\mathrm{SH}+\mathrm{CH}_{3} & \leftrightarrow \mathrm{H}_{2}+\mathrm{CH}_{2} \mathrm{~S} \\
\mathrm{H}+\mathrm{CH}_{3} \mathrm{SH} & \leftrightarrow \mathrm{CH}_{3}+\mathrm{H}_{2} \mathrm{~S} \\
\mathrm{H}+\mathrm{CH}_{3} \mathrm{SH} & \leftrightarrow \mathrm{CH}_{3} \mathrm{~S}+\mathrm{H}_{2} \\
\mathrm{H}+\mathrm{CH}_{3} \mathrm{~S} & \leftrightarrow \mathrm{CH}_{2} \mathrm{~S}+\mathrm{H}_{2} \\
\mathrm{H}+\mathrm{CH}_{2} \mathrm{~S} & \leftrightarrow \mathrm{HCS}+\mathrm{H}_{2} \\
\mathrm{H}+\mathrm{HCS} & \leftrightarrow \mathrm{H}_{2}+\mathrm{CS} \\
\mathrm{SH}+\mathrm{CS} & \leftrightarrow \mathrm{H}+\mathrm{CS}_{2}
\end{aligned}
$$

Their model agreed fairly well with the experimental data, and even experimental errors in the species concentrations have been taken into consideration [21].

2.3.5. The Role of $\mathrm{SO}_{2}$ in Kinetic Mechanisms. As we can see from the oxidation paths of $\mathrm{H}_{2} \mathrm{~S}, \mathrm{SO}_{2}$ is a predominant product. And, $\mathrm{SO}_{2}$ will take part in the following Claus reaction in the Claus reactor as a major reactant. In the thermal reactor, $\mathrm{SO}_{2}$ is not likely to be oxidized to $\mathrm{SO}_{3}$ because of the lack of combustion air. Mueller et al. [29] showed that the increasing concentration of $\mathrm{SO}_{2}$ progressively decreases the oxidation of $\mathrm{CO}$, highlighting a good agreement between literature data and model predictions. 
Dagaut et al. [30] showed that the inhibition effect is progressively reduced with higher temperatures for the cases of stoichiometric and lean inlet oxygen. In the thermal reactor, $\mathrm{CS}_{2}$ and $\mathrm{COS}$ can react with $\mathrm{O}$ radicals which were provided by the thermal decomposition of $\mathrm{SO}_{2}$. The chemical paths are as follows:

$$
\begin{aligned}
& \mathrm{COS}+\mathrm{O} \leftrightarrow[\mathrm{S}-\mathrm{C}(\mathrm{O}) \equiv \mathrm{O}]^{*} \leftrightarrow \mathrm{CO}_{2}+\mathrm{S} \\
& \mathrm{COS}+\mathrm{O} \leftrightarrow[\mathrm{O}-\mathrm{S}-\mathrm{C} \equiv \mathrm{O}]^{*} \leftrightarrow \mathrm{CO}+\mathrm{SO} \\
& \mathrm{CS}_{2}+\mathrm{O} \leftrightarrow[\mathrm{S}-\mathrm{C}(\mathrm{O}) \equiv \mathrm{S}]^{*} \leftrightarrow \mathrm{COS}+\mathrm{S}
\end{aligned}
$$

2.3.6. The Oxidation of Methane. In some industrial thermal reactors, $\mathrm{CH}_{4}$ is used for ignition and to maintain the temperature. The overall scheme for the combustion of methane is well known, and it involves, depending on the conditions, species such as $\mathrm{CH}_{3}, \mathrm{CH}_{2} \mathrm{O}, \mathrm{CHO}, \mathrm{CO}, \mathrm{CO}_{2}$, $\mathrm{C}_{2} \mathrm{H}_{6}, \mathrm{C}_{2} \mathrm{H}_{4}, \mathrm{C}_{2} \mathrm{H}_{2}, \mathrm{CH}_{2}, \mathrm{CH}, \mathrm{C}_{3} \mathrm{H}_{3}$, and $\mathrm{C}_{6} \mathrm{H}_{6}$. [31] The twocarbon molecules become more important under fuel-rich conditions. The research by Westbrook and Dryer [32] was meaningful, and they showed that the methane combustion in the atmosphere with hydrogen sulfide under fuel-rich conditions was initiated by

$$
\begin{gathered}
\mathrm{CH}_{4}+\mathrm{S} \leftrightarrow \mathrm{CH}_{3}+\mathrm{HS} \\
\mathrm{CH}_{4}+\mathrm{HS} \leftrightarrow \mathrm{CH}_{3}+\mathrm{H}_{2} \mathrm{~S}
\end{gathered}
$$

Through the above reactions, sulfur species can affect the main chemical paths for methane oxidation.

\section{Reactor Network Analysis Model}

3.1. Settings of the RNA Model. We used Chemkin Pro to do the analysis, and the scheme of the RNA model is shown in Figure 3. According to Pierucci et al. [33], a perfectly mixed reactor was adopted to describe the mix of acid gas and air. In the model, $\mathrm{H}_{2} \mathrm{~S}$ was oxidized to $\mathrm{SO}_{2}$ as soon as it met $\mathrm{O}_{2}$, while the other species were assumed inert because of the fast ignition of $\mathrm{H}_{2} \mathrm{~S}$ concerning the other species.

We used a plug flow reactor (PFR) to simulate the thermal reactor by defining the diameter along with the distance. A smaller diameter was used to represent the transition section between the burner and the reactor. Residence time is a key factor influencing the chemical process, and the residence time in this process is more precise in this way.

The acid gas starts to burn at the thermal burner and continues to react in the thermal reactor. Chemical equilibrium is supposed to reach before the outlet of the thermal reactor because of sufficient residence time, so the gas concentration at the end of the thermal reactor is even. The tubes in the waste boiler are the same and independent, so the chemical process and products in different tubes are the same. As a result, a PFR was used to represent one tube in the waste boiler. In the work by Manenti et al. [11, 13], the whole waste boiler was also considered as one tube, so the inlet flow rate and the structure size were not appropriate. In our simulation model, a gas flow splitter (GFS) was used. A certain part of the gas of the thermal reactor was injected into the waste boiler, while the other part of the tail gas was directly transported to the first outlet. The product at this outlet is the same as the product of the thermal reactor. The inlet flow rate of this PFR was calculated according to the number of the tubes in the waste boiler, and the structure size of this PFR was set as the same as the real tube. Through the settings mentioned above, the residence time in the waste boiler was precisely controlled.

For the thermal reactor, the heat transfer can be assumed to be zero because of the adiabatic layer at the outside. For the waste heat boiler, the heat exchange is fierce because of the condensation effect. The tubes in the waste boiler were assumed to be clean, and the heat transfer coefficient was determined only by the heat convection between the gas and the tubes.

3.2. Verification of the RNA Model. A new RNA model with a revised mechanism has been set up according to the introduction above, and before applying this approach, verification was done. The industrial data were adopted from the research by Manenti et al. [15]. The structure parameters and inlet operating conditions are listed in Table 3.

The temperature profile is shown in Figure 4. The value of the temperature at the outlet of WHB is consistent with the industrial data. The temperature in the TR is stable because the layer was adiabatic, and the reaction heat can maintain the temperature. The temperature at the beginning of the WHB has a sharp drop because of the cooling water. The speed of temperature falling decreases with the increase of the reactor length and the residence time because of the decrease in the temperature gradient between the gas and the cooling water.

The gas-phase species composition along the thermal reactor and the waste heat boiler is shown in Figures 5 and 6 . Results show that the mole fraction at the beginning of TR changes fiercely and gets to equilibrium long before the exit of the TR. Then in the WHB, the equilibrium and kinetics shift because of the rapid change of temperature. As we can see, the simulation result matches the experimental data very well. The mole fraction of $\mathrm{H}_{2} \mathrm{~S}$ decreases in the TR because of its oxidation and pyrolysis, while it increases in TR because of the change of chemical equilibrium. The formation of $\mathrm{S}_{2}$ leads to a sharp rise in mole fraction at the beginning of TR, and then the mole fraction of $\mathrm{S}_{2}$ decreases sharply in WHB caused by the formation of the sulfur isomers.

Due to the oxidation and pyrolysis of $\mathrm{H}_{2} \mathrm{~S}$, the mole fractions of $\mathrm{SO}_{2}$ and $\mathrm{H}_{2}$ have a huge increase at the inlet. And, in the WHB, the mole fractions of $\mathrm{H}_{2}$ and $\mathrm{S}_{2}$ have a sharp drop, while the mole fraction of $\mathrm{H}_{2} \mathrm{~S}$ has an equivalent increase because of the shift of the chemical equilibrium. With the continuing falling of temperature in $\mathrm{WHB}$, the mole fractions of most species remain the same except for $\mathrm{S}_{2}$.

In Manenti et al's work, gas quenching was set at position $7.5 \mathrm{~m}$ (corresponding at temperature $950^{\circ} \mathrm{C}$ ) and industrial $\mathrm{S}_{2}$ data were collected at this position. The mole fraction of $S_{2}$ at $7.5 \mathrm{~m}$ is 0.0587 which is in accordance with the industrial data (5.9\%). After this position, $\mathrm{S}_{2}$ transforms 


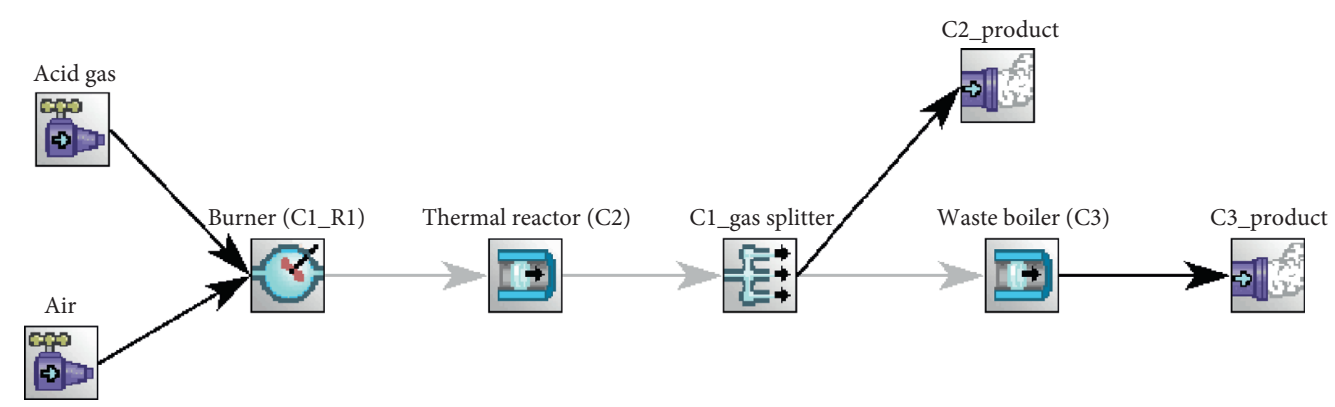

FIgURE 3: The scheme of the RNA.

TABLE 3: The structure parameters and inlet operating condition.

\begin{tabular}{lc}
\hline Parameters & Value \\
\hline Acid gas composition (vol \%) & $\mathrm{C}_{2} \mathrm{H}_{6}(1.40), \mathrm{CH}_{4}(2.1), \mathrm{CO}_{2}(6.62), \mathrm{H}_{2} \mathrm{O}(6.40), \mathrm{H}_{2} \mathrm{~S}(79.55), \mathrm{H}_{2}(3.7), \mathrm{NH}_{3}(0.48)$, \\
$\mathrm{C}_{3} \mathrm{H}_{8}(1.98), \mathrm{CO}(0.32), \mathrm{H}_{2} \mathrm{O}(6.4)$ \\
Acid gas flow rate & $4230.5 \mathrm{~kg} / \mathrm{h}$ \\
Acid gas temperature & $125^{\circ} \mathrm{C}$ \\
Combustion air composition (vol \%) & $\mathrm{H}_{2} \mathrm{O}(9.70), \mathrm{N}_{2}(71.38), \mathrm{O}_{2}(18.92)$ \\
Combustion air flow rate & $8907.1 \mathrm{~kg} / \mathrm{h}$ \\
Combustion air temperature & $45^{\circ} \mathrm{C}$ \\
Operating pressure & $159 \mathrm{kPa}$ \\
Reactor length & $6.5 \mathrm{~m}$ \\
Reactor diameter & $1.55 \mathrm{~m}$ \\
WHB tube length & $6.00 \mathrm{~m}$ \\
WHB tube number & 470 \\
WHB tube diameter & $0.050 \mathrm{~m}$ \\
\hline
\end{tabular}

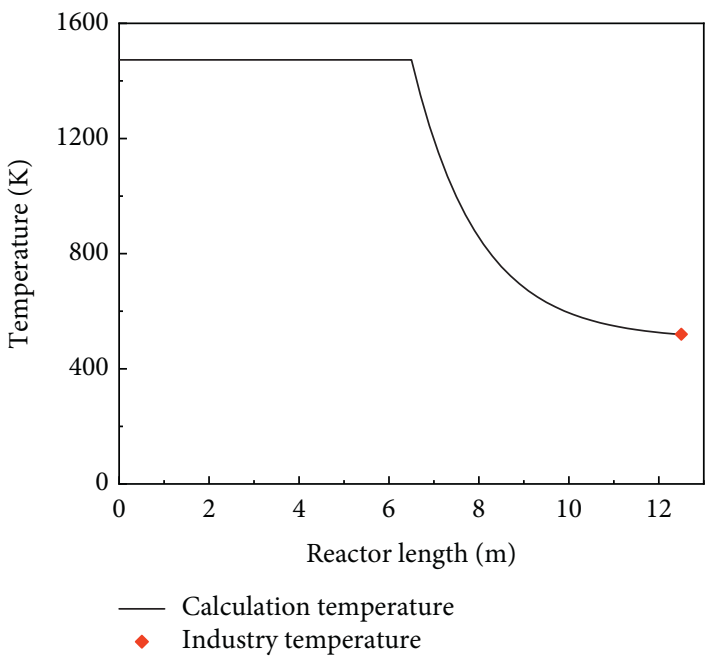

(a)

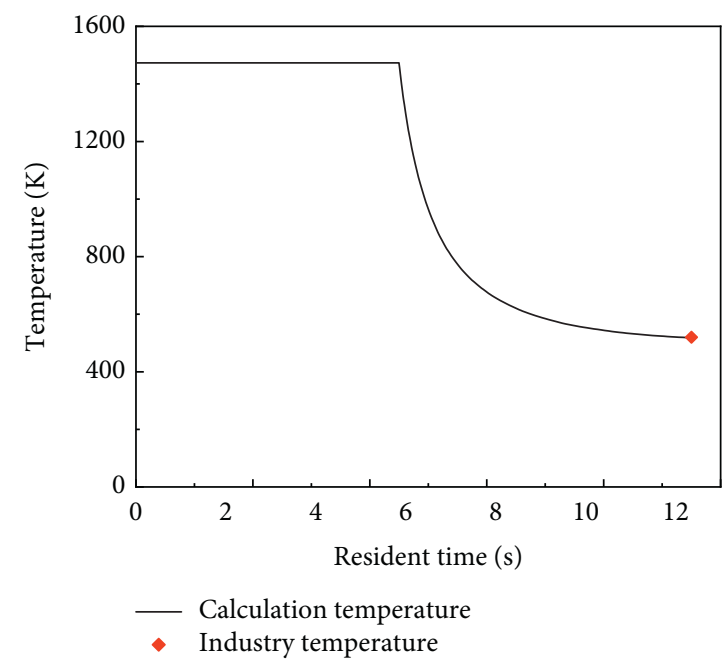

(b)

FIgURE 4: Temperature (K) profile in the TR and WHB.

into other sulfur isomers (shown in Figure 7). There are 8 allotropes $\left(S_{1}-S_{8}\right)$ of sulfur, and their transition is highly temperature dependent. Among all the isomers, $S_{2}$ and $S_{8}$ are the most stable ones. $S_{2}$ remains stable above $600 \mathrm{~K}$, while $S_{8}$ is dominant when the temperature is below this value. As we can conclude from Figure 7 , all of the $S_{2}$ have converted to other types of sulfur allotropes due to the temperature drop, and the dominant products are $\mathrm{S}_{6}, \mathrm{~S}_{7}$, and $\mathrm{S}_{8}$.

Based on the calculation result above, we did an error analysis to compare the results between our work and Manenti et al's work (shown in Figure 8). In Figure 8, different colors are used to represent different species and 


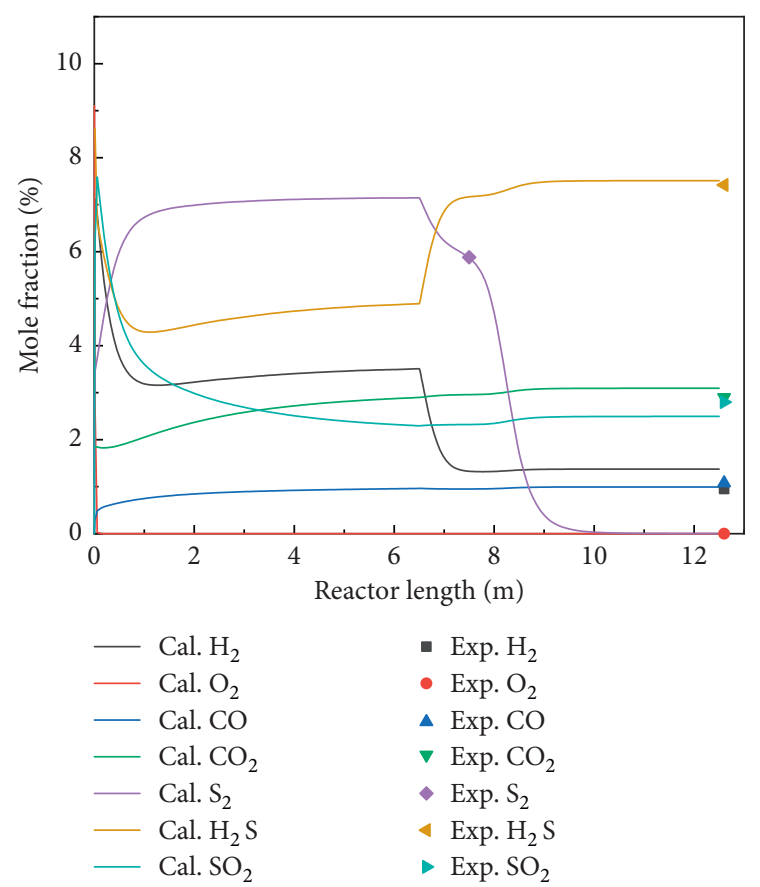

FIgURE 5: Gas-phase species composition along with the TR and WHB of industrial data and the calculation result.

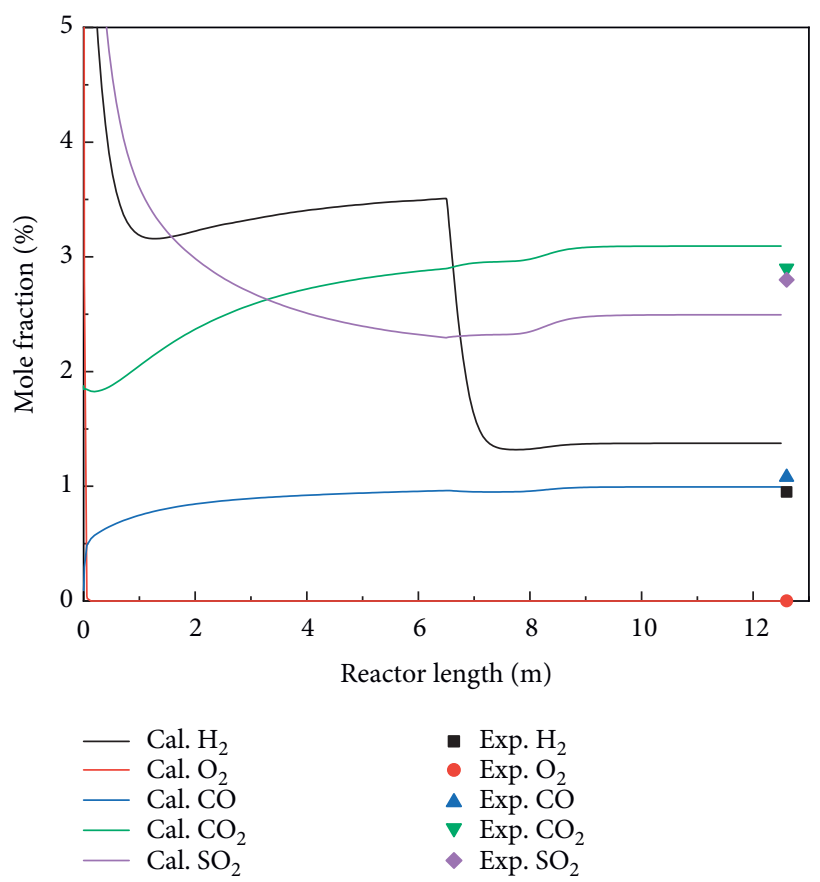

FIGURE 6: Gas-phase species composition along with the TR and WHB of industrial data and the calculation result (magnified).

squares represent Manenti et al's results while dots represent our results. As we can see, our calculation results have a better prediction in the concentration of all these species except for $\mathrm{CO}$, and the deviations of the $\mathrm{CO}$ concentration is acceptable.

Through the analysis above, we can see that the new RNA model with a revised mechanism can not only describe the

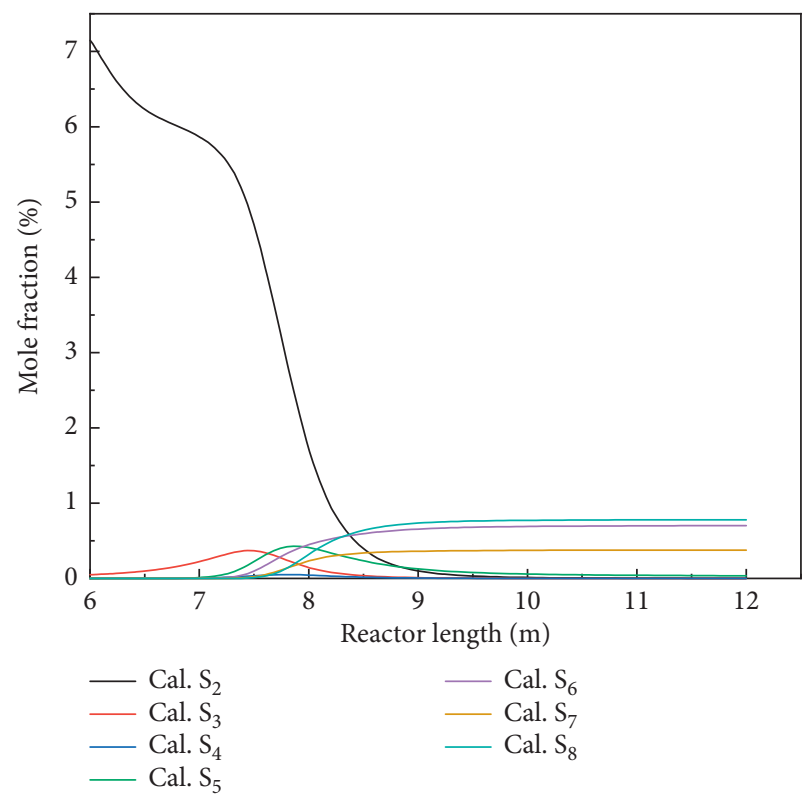

Figure 7: The formation of the sulfur isomers.

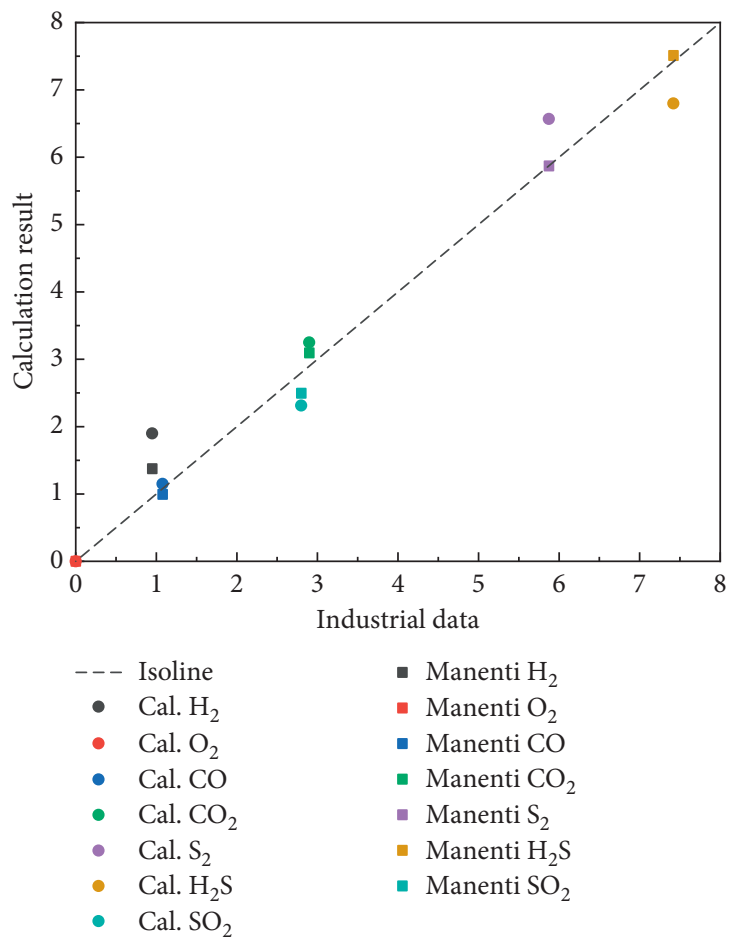

FIgURE 8: The residuals of the calculated concentration.

key features in SRUs but also predict the concentration with good accuracy.

\section{Optimization Research}

4.1. Sulfur Recovery Efficiency. After the verification, we did the parameter optimization study of the burner used in a real factory. This optimization research aimed to obtain the highest sulfur recovery efficiency and in this way will $\mathrm{H}_{2} \mathrm{~S}$ do 
the least harm to the environment. To estimate the $\mathrm{H}_{2} \mathrm{~S}$ conversion, sulfur recovery efficiency was defined as follows:

$$
E_{s}=\frac{S_{\text {at the exit of SRUs }}}{S_{\text {at the inlet of SRUs }}}=\frac{S_{\text {at the exit of WHB }}+S_{\text {at the exit of CR }}}{S_{\text {at the inlet of SRUs }}},
$$

where $E_{s}$ stands for the sulfur recovery efficiency and $S$ stands for the total amount of all the allotropes of sulfur, and its unit is $\mathrm{g} / \mathrm{s}$. The reaction of $\mathrm{H}_{2} \mathrm{~S}$ and $\mathrm{SO}_{2}$ in real $\mathrm{CR}$ is always complete, so $S_{\text {at }}$ the exit of CR can be calculated by equation (2) as follows:

$$
S_{\text {at the exit of } \mathrm{CR}}= \begin{cases}\frac{3}{2} \times S_{\mathrm{SO}_{2} \text { at the inlet of } \mathrm{CR},} & \left(\text { if } \frac{C_{\mathrm{H}_{2} \text { at the inlet of } \mathrm{CR}}}{\mathrm{C}_{\mathrm{SO}_{2}} \text { at the inlet of } \mathrm{CR}} \geq 2\right), \\ \frac{3}{4} \times S_{\mathrm{H}_{2} \mathrm{~S} \text { at the inlet of } \mathrm{CR},} & \left(\text { if } \frac{C_{\mathrm{H}_{2} \mathrm{~S} \text { at the inlet of } \mathrm{CR}}}{\mathrm{C}_{\mathrm{SO}_{2} \text { at the inlet of } \mathrm{CR}}} \leq 2\right),\end{cases}
$$

where the mass flow rates of $\mathrm{SO}_{2}$ and $\mathrm{H}_{2} \mathrm{~S}$ at the inlet of $\mathrm{CR}$ are equal to those at the exit of WHB.

4.2. Parameter Optimization Study. In our work, the excess air coefficient, temperature in TR $\left(T_{\mathrm{TR}}\right)$, and temperature of the cooling water $\left(T_{\mathrm{cw}}\right)$ were studied. These three parameters can be adjusted easily in the factory. The excess air coefficient and $T_{\mathrm{TR}}$ are decided by the amount of fuel and air. The SRUs studied in our paper are located at the Puguang gas field, China. The relating structure parameters and inlet operating conditions are listed in Table 4.

4.2.1. Excess Air Coefficient. The excess air coefficient is controlled by the ratio of acid air to gas. And, from equations (1) and (2), we can see that the best stoichiometric ratio for the complete reaction of $\mathrm{H}_{2} \mathrm{~S}$ and $\mathrm{O}_{2}$ is 2 . The excess air coefficient is defined as the ratio of the actual amount of air to the amount required for complete combustion of fuel (stoichiometric amount). In a real factory, the excess air coefficient is not always 1 because there are other species in acid gas other than $\mathrm{H}_{2} \mathrm{~S}$, taking parting in the subsequent reactions. So, it is useful to find out the best excess air coefficient to gain the highest sulfur recovery efficiency. In this paper, the excess air coefficient varied from 0.7 to 1.4 , which means the ratio of the actual amount of air to the stoichiometric amount was from 0.7 to 1.4 .

The results are shown in Figure 9. The sulfur recovery efficiency first has an increase and then a decrease with the excess air coefficient varying from 0.7 to 1.4 . There is a maximum that lies between 0.9 and 1 where the sulfur recovery efficiency is beyond $95 \%$. This result is reasonable because both too much and too little air will affect the conversion of $\mathrm{H}_{2} \mathrm{~S}$. From Figure 9, we can see that the peak point is located near 0.93 and the corresponding sulfur recovery efficiency is beyond $98 \%$.

4.2.2. Temperature in TR. From the verification result, we can see that the concentration of many species changed fiercely near the inlet of the TR. And, after the reactions take place in TR, the gas should contain appropriate $\mathrm{H}_{2} \mathrm{~S}$ and
$\mathrm{SO}_{2}$. We have reason to believe the temperature in $\mathrm{TR}$ is important to the conversion of $\mathrm{H}_{2} \mathrm{~S}$. The TR temperature was decided by the amount of fuel. The more the fuel, the higher the TR temperature. The research result of temperature is shown in Figure 10. The sulfur recovery efficiency is not a monotone function of temperature in TR. As the temperature varied from $1073 \mathrm{~K}$ to $1473 \mathrm{~K}$, the sulfur recovery efficiency increased clearly at first and then increased with a much slower speed. And at last, it had a significant drop with the increase in temperature. This curve had a peak near $1273 \mathrm{~K}$. This result indicates that the temperature did have a clear influence on the whole sulfur recovery process. Higher temperature means more fuel, and more fuel means more sulfur recovery speed. So, $1273 \mathrm{~K}$ was chosen to be the optimum TR temperature in the sulfur recovery process.

4.2.3. Temperature of Cooling Water. From the verification result above, the equilibrium and kinetics in WHB were different from those in TR because of the rapid change of the temperature. So, the change speed of the temperature which is decided by the temperature of the cooling water is important to this process. Different temperatures of the cooling water will result in different WHB outlet temperatures (shown in Figure 11). With the increase of the cooling water temperature, the gas temperature at WHB outlet increased. The lower the cooling water temperature, the more the gas temperature at the WHB outlet dropped with the same residence time and the faster the decrease in the gas temperature in WHB. This result was reasonable. The greater the temperature gradient was, the more powerful the heat transfer was.

The sulfur recovery efficiency as a function of the cooling water temperature is shown in Figure 12. Although the gas temperature at the WHB outlet was influenced by the cooling water temperature obviously, the sulfur recovery efficiency had little reaction to the change of this temperature. With the increase of the cooling water temperature, the sulfur recovery efficiency only had a very slight increase which can be ignored. So, the temperature of the cooling water is always set to the temperature which can help to obtain the highest heat efficiency of the WHB. 
TABle 4: The structure parameters and inlet operating condition in the Puguang gas field.

\begin{tabular}{lc}
\hline Parameters & Value \\
\hline Acid gas composition (mole \%) & $\mathrm{CH}_{4}(0.21), \mathrm{CO}_{2}(32.28), \mathrm{H}_{2} \mathrm{O}(6.97), \mathrm{H}_{2} \mathrm{~S}(60.52), \mathrm{COS}(0.01)$ \\
Acid gas flow rate & $46827 \mathrm{~kg} / \mathrm{h}$ \\
Acid gas temperature & $50^{\circ} \mathrm{C}$ \\
Combustion air composition (mole \%) & $\mathrm{H}_{2} \mathrm{O}(6.5), \mathrm{N}_{2}(73.91), \mathrm{O}_{2}(19.59)$ \\
Combustion air flow rate & $53530 \mathrm{~kg} / \mathrm{h}$ \\
Combustion air temperature & $108^{\circ} \mathrm{C}$ \\
Operating pressure & $159 \mathrm{kPa}$ \\
Reactor length & $6 \mathrm{~m}$ \\
Reactor diameter & $2.5 \mathrm{~m}$ \\
WHB tube length & $6.00 \mathrm{~m}$ \\
WHB tube number & 500 \\
WHB tube diameter & $0.074 \mathrm{~m}$ \\
\hline
\end{tabular}

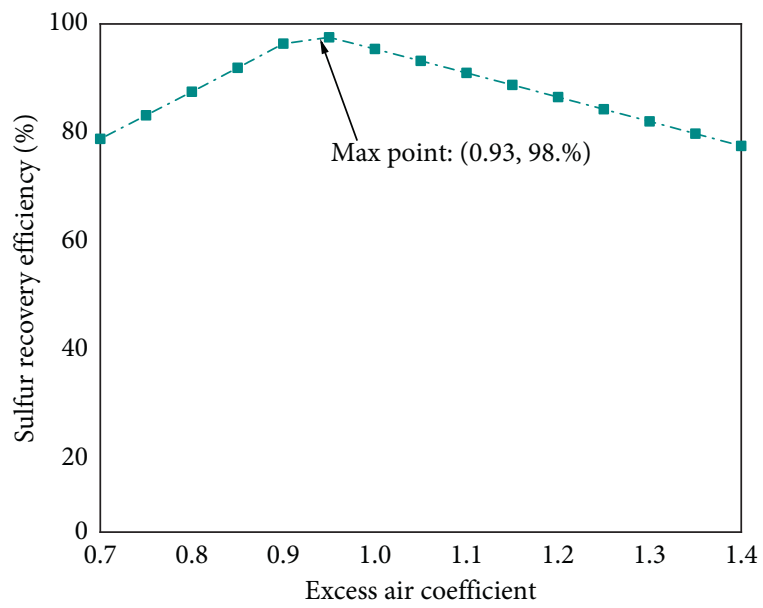

FIgURE 9: Sulfur recovery efficiency as a function of the excess air coefficient.

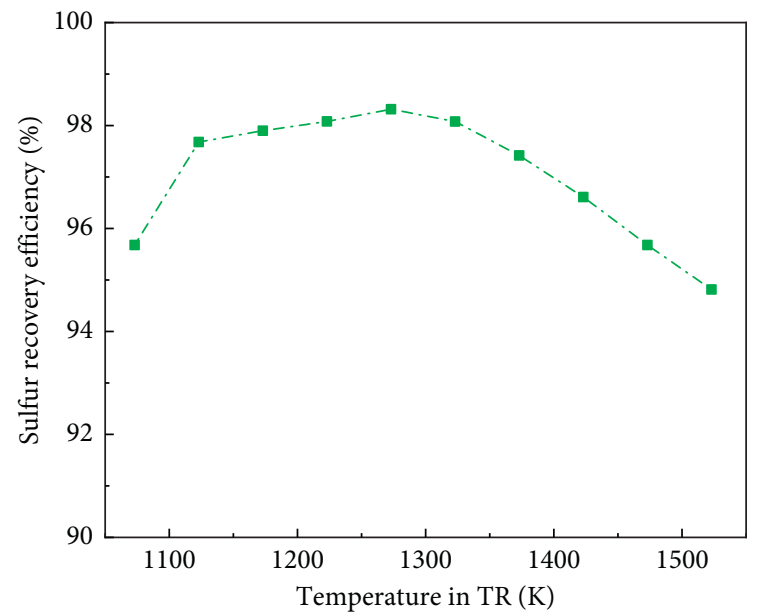

FIGURE 10: Sulfur recovery efficiency as a function of temperature in TR.

4.3. Test in Factory. Before we tested the calculation result, we recorded an original copy of the industrial data in the Puguang gas field in China. The original operating parameters of SRUs are as follows:

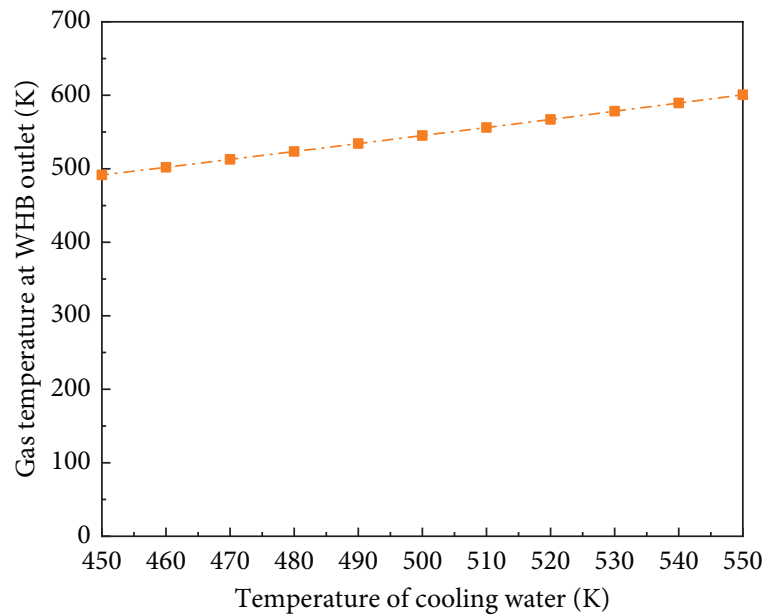

Figure 11: The gas temperature at the WHB outlet as a function of the temperature of cooling water.

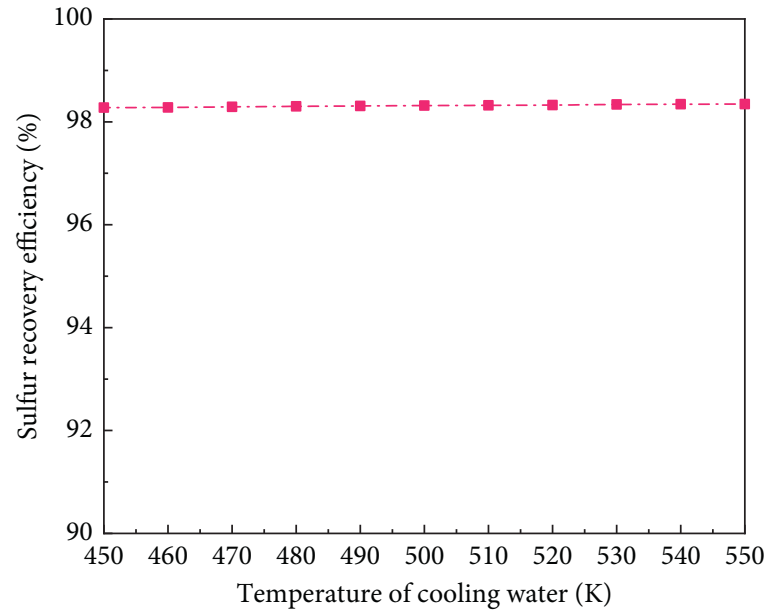

FIGURE 12: Sulfur recovery efficiency as a function of the temperature of cooling water.

$$
\begin{aligned}
\mathrm{Q}_{\text {acid gas }, 1} & =46827 \mathrm{~kg} / \mathrm{h}, \mathrm{Q}_{\text {air, } 1}=53530 \mathrm{~kg} / \mathrm{h}, \\
\mathrm{T}_{\mathrm{TR}, 1} & =1270 \mathrm{~K}, \text { and } \mathrm{T}_{\mathrm{CW}, 1}=500 \mathrm{~K} .
\end{aligned}
$$




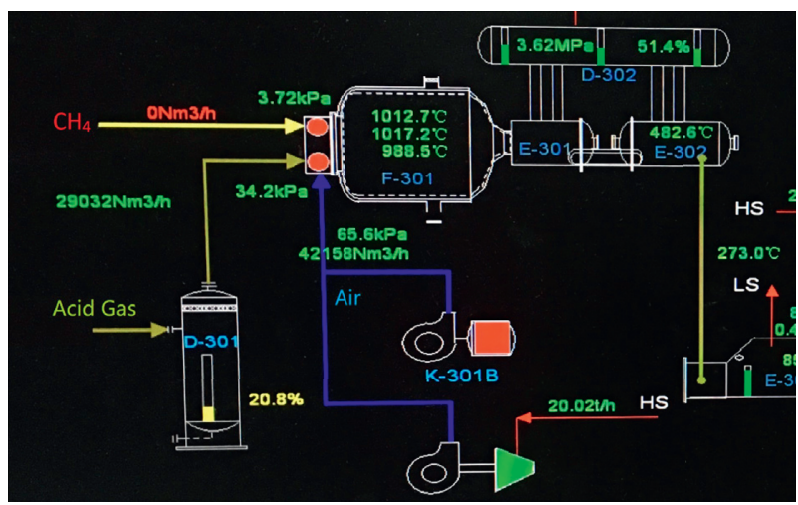

Figure 13: The display screen of the central controller in the Puguang gas field (test situation).

TABLE 5: Original industrial data and the optimization result.

\begin{tabular}{lcc}
\hline & Original situation & Optimization situation \\
\hline Acid gas $(\mathrm{kg} / \mathrm{s})$ & 13.007 & 13.007 \\
Air $(\mathrm{kg} / \mathrm{s})$ & $\mathbf{1 4 . 8 6 9}$ & $\mathbf{1 4 . 7 1 1}$ \\
Excess air coefficient & $\mathbf{0 . 9 5 5}$ & $\mathbf{0 . 9 4 5}$ \\
Temperature in TR $(\mathrm{K})$ & $\mathbf{1 2 7 0}$ & $\mathbf{1 2 8 0}$ \\
Temperature of cooling water $(\mathrm{K})$ & 500 & 500 \\
Sulfur production $(\mathrm{kg} / \mathrm{s})$ & $\mathbf{6 . 6 9 8}$ & $\mathbf{6 . 8 0 1}$ \\
Sulfur recovery efficiency $(\%)$ & $\mathbf{9 6 . 0 7 \%}$ & $\mathbf{9 7 . 5 4} \%$ \\
\hline
\end{tabular}

The sulfur recovery process is a complex industrial process, and it involves so many devices and operations in a real factory that we cannot just simply change the operating parameters as we want. So, after the discussion with the engineers in the factory and considering the optimum operating condition above, the test parameters were as follows:

$$
\begin{aligned}
\mathrm{Q}_{\text {acid gas }, 2}= & 46827 \mathrm{~kg} / \mathrm{h}, \mathrm{Q}_{\mathrm{air}, 2}=52961 \mathrm{~kg} / \mathrm{h}, \\
& \mathrm{T}_{\mathrm{TR}, 2}=1280 \mathrm{~K} \text {, and } \mathrm{T}_{\mathrm{CW}, 2}=500 \mathrm{~K} .
\end{aligned}
$$

The flow rate acid gas and the temperature of cooling water in these two situations stayed the same. Figure 13 shows the display screen of the central controller in the Puguang gas field when we tested the optimization parameters. We can see the flow rate of acid gas and air in Figure 13: $Q_{\text {acid gas, } 1}=Q_{\text {acid gas, } 2}=46827 \mathrm{~kg} / \mathrm{h}=(46827 / 36.13) \times 22.4 \mathrm{Nm}^{3} /$ $\mathrm{h}=29032 \mathrm{Nm}^{3} / \mathrm{h}$ and $Q_{\text {acid gas, } 2}=52961 \mathrm{~kg} / \mathrm{h}=(52961 / 28.14) \times$ $22.4 \mathrm{Nm}^{3} / \mathrm{h}=42158 \mathrm{Nm}^{3} / \mathrm{h}$. And, after calculation, the corresponding excess air coefficient was 0.945 .

The comparison of the original situation and test situation is shown in Table 5. The main difference between these two situations was the flow rate of air, which decided the excess air coefficient. The sulfur recovery efficiency in the test situation was higher than that in the original situation, which was consistent with the rules of the effect of the excess air coefficient. In the optimization research, the sulfur recovery efficiency decreased with the excess air coefficient changing from 0.93 to 1 .

The test result proved our RNA model was reliable, and it can be a useful tool in the industry. But due to the complexity of the SRUs, we cannot test every possible situation. In our following work, we will improve our RNA model and try to make it capable of investigating the effect of all other parameters. Then, a detailed optimization result will be obtained and tested in the factory.

\section{Conclusions}

This paper has focused on the optimization of the operating parameters that affect the sulfur recovery efficiency of the SRUs. To get the optimum operating condition, we built a combustion mechanism and a reactor network analysis model to predict the concentration in the Claus process. The calculation results were verified with the industrial data and compared with the work of other researchers. After the verification, the optimization research of real SRUs located in the Puguang gas field was done. Then, the optimum excess air coefficient, temperature in TR, and temperature of the cooling water were obtained. At last, the obtained parameters were tested in the Puguang gas field. Based on the results mentioned above, the following conclusions may be drawn:

(1) The RNA model with the revised mechanism which includes 94 species and 615 elementary reactions had a good predication of the TR and WHB. Because of the more accurate residence time in our model, the calculation results were highly consistent with the industrial data and even more accurate than other researcher's results.

(2) Through the optimization research, we find that the excess air coefficient and the temperature in TR had a clear influence on the sulfur recovery efficiency, while different temperatures of the cooling water 
made little difference to the results. After the analysis, the optimum condition parameters were set as follows: excess air coefficient $=0.93, T_{\mathrm{TR}}=1273^{\circ} \mathrm{K}$, and $T_{\mathrm{CW}}=500^{\circ} \mathrm{K}$. The corresponding sulfur recovery efficiency was about $98.3 \%$.

(3) The above parameters were tested in real SRUs, and the sulfur recovery efficiency had a clear increase after our optimization research. The whole result had a positive attitude towards the RNA model with the revised mechanism, and it proved that our new approach was a useful tool in the industry.

\section{Data Availability}

All data, models, and code generated or used during the study are included within the article.

\section{Conflicts of Interest}

The authors declare that they have no conflicts of interest.

\section{Acknowledgments}

This study was funded by the National Major Science and Technology Projects of China (2016ZX05017-006), Program for New Century Excellent Talents in University (NCET-130468), and Fundamental Research Funds for the Central Universities.

\section{References}

[1] R. N. Maddox, Gas Conditioning and Processing: Gas and Liquid Sweetening, Campbell Petroleum Series, Oklahoma, OK, USA, 1982.

[2] F. Manenti, D. Papasidero, and E. Ranzi, "Revised kinetic scheme for thermal furnace of sulfur recovery units," AIDIC Conference Series, vol. 32, pp. 1185-1290, 2013.

[3] S. Ibrahim and A. Raj, "Kinetic simulation of acid gas $\left(\mathrm{H}_{2} \mathrm{~S}\right.$ and $\mathrm{CO}_{2}$ ) destruction for simultaneous syngas and sulfur recovery," Industrial \& Engineering Chemistry Research, vol. 55, no. 24, pp. 132-145, 2016.

[4] N. J. Nabikandi and S. Fatemi, "Kinetic modelling of a commercial sulfur recovery unit based on Claus straight through process: comparison with equilibrium model," Journal of Industrial \& Engineering Chemistry, vol. 30, pp. 1570-1586, 2015.

[5] A. K. Gupta, S. Ibrahim, and A. Al Shoaibi, "Advances in sulfur chemistry for treatment of acid gases," Progress in Energy and Combustion Science, vol. 54, pp. 65-92, 2016.

[6] S. Ibrahim, R. K. Rahman, and A. Raj, "Roles of hydrogen sulfide concentration and fuel gas injection on aromatics emission from claus furnace," Chemical Engineering Science, vol. 172, pp. 513-527, 2017.

[7] H. R. Mahdipoor and A. Dehghani Ashkezari, "Feasibility study of a sulfur recovery unit containing mercaptans in lean acid gas feed," Journal of Natural Gas Science and Engineering, vol. 31, pp. 585-588, 2016.

[8] T. Y. Cong, A. Raj, J. Chanaphet, S. Mohammed, S. Ibrahim, and A. Al Shoaibi, "A detailed reaction mechanism for hydrogen production via hydrogen sulphide $\left(\mathrm{H}_{2} \mathrm{~S}\right)$ thermolysis and oxidation," International Journal of Hydrogen Energy, vol. 41, no. 16, pp. 6662-6675, 2016.
[9] B. Mahmoodi, S. H. Hosseini, G. Ahmadi, and A. Raj, "CFD simulation of reactor furnace of sulfur recovery units by considering kinetics of acid gas $\left(\mathrm{H}_{2} \mathrm{~S}\right.$ and $\left.\mathrm{CO}_{2}\right)$ destruction," Applied Thermal Engineering, vol. 123, pp. 699-710, 2017.

[10] A. Ravikumar, A. Raj, S. Ibrahim et al., "Kinetic simulations of $\mathrm{H}_{2}$ production from $\mathrm{H}_{2} \mathrm{~S}$ pyrolysis in sulfur recovery units using a detailed reaction mechanism," Energy \& Fuels, vol. 30, no. 12, 2016.

[11] F. Manenti, D. Papasidero, G. Bozzano, and E. Ranzi, "Modelbased optimization of sulfur recovery units," Computers \& Chemical Engineering, vol. 66, pp. 244-251, 2014.

[12] F. Manenti, D. Papasidero, A. Cuoci et al., "Reactor network analysis of Claus furnace with detailed kinetics," Computer Aided Chemical Engineering, vol. 30, pp. 1007-1012, 2012.

[13] F. Manenti, D. Papasidero, A. Frassoldati, G. Bozzano, S. Pierucci, and E. Ranzi, "Multi-scale modeling of Claus thermal furnace and waste heat boiler using detailed kinetics," Computers \& Chemical Engineering, vol. 59, pp. 219-225, 2013.

[14] F. Manenti, D. Papasidero, and E. Ranzi, "Revised kinetic scheme for thermal furnace of sulfur recovery units," Chemical Engineering Transactions, vol. 32, pp. 1285-1290, 2013.

[15] G. Manenti, D. Papasidero, F. Manenti, G. Bozzano, and S. Pierucci, "Design of SRU thermal reactor and waste heat boiler considering recombination reactions," Procedia Engineering, vol. 42, pp. 376-383, 2012.

[16] M. Binoist, B. Labégorre, F. Monnet et al., "Kinetic study of the pyrolysis of $\mathrm{H}_{2} \mathrm{~S}$," Industrial \& Engineering Chemistry Research, vol. 42, no. 17, pp. 3943-3951, 2003.

[17] Y. Li, X. Yu, Q. Guo, Z. Dai, G. Yu, and F. Wang, "Kinetic study of decomposition of $\mathrm{H}_{2} \mathrm{~S}$ and $\mathrm{CH}_{4}$ for $\mathrm{H}_{2}$ production using detailed mechanism," Energy Procedia, vol. 142, pp. 1065-1070, 2017.

[18] C. Zhou, K. Sendt, and B. S. Haynes, "Experimental and kinetic modelling study of $\mathrm{H}_{2} \mathrm{~S}$ oxidation," Proceedings of the Combustion Institute, vol. 34, no. 1, pp. 625-632, 2013.

[19] Y. Li, Y. Lin, Z. Xu, B. Wang, and T. Zhu, "Oxidation mechanisms of $\mathrm{H}_{2} \mathrm{~S}$ by oxygen and oxygen-containing functional groups on activated carbon," Fuel Processing Technology, vol. 189, pp. 110-119, 2019.

[20] D. Barba, F. Cammarota, V. Vaiano et al., "Experimental and numerical analysis of the oxidative decomposition of $\mathrm{H}_{2} \mathrm{~S}$," Fuel, vol. 198, pp. 68-75, 2016.

[21] I. A. Gargurevich, "Hydrogen sulfide combustion: relevant issues under claus furnace conditions," Industrial \& Engineering Chemistry Research, vol. 44, no. 20, pp. 7706-7729, 2005.

[22] V. A. Savelieva, N. S. Titova, and A. M. Starik, "Modeling study of hydrogen production via partial oxidation of $\mathrm{H}_{2} \mathrm{~S}$ $\mathrm{H}_{2} \mathrm{O}$ blend," International Journal of Hydrogen Energy, vol. 42, no. 16, pp. 10854-10866, 2017.

[23] Y. Li, X. Yu, H. Li et al., "Detailed kinetic modeling of homogeneous $\mathrm{H}_{2} \mathrm{~S}-\mathrm{CH}_{4}$ oxidation under ultra-rich condition for $\mathrm{H}_{2}$ production," Applied Energy, vol. 208, pp. 905-919, 2017.

[24] A. J. Hynes and P. H. Wine, Gas-phase Combustion Chemistry: Kinetics and Mechanisms of the Oxidation of Gaseous Sulfur Compounds, Springer-Verlag, New York, NY, USA, 2000.

[25] M. Abián, M. Cebrián, Á. Millera, R. Bilbao, and M. U. Alzueta, " $\mathrm{CS}_{2}$ and $\mathrm{COS}$ conversion under different combustion conditions," Combustion and Flame, vol. 162, no. 5, pp. 2119-2127, 2015.

[26] K. Karan, A. K. Mehrotra, and L. A. Behie, "A high-temperature experimental and modeling study of homogeneous 
gas-phase COS reactions applied to claus plants," Chemical Engineering Science, vol. 54, no. 15-16, pp. 2999-3006, 1999.

[27] W. D. Monnery, W. Y. Svrcek, and L. A. Behie, "Modelling the modified claus process reaction furnace and the implications on plant design and recovery," The Canadian Journal of Chemical Engineering, vol. 71, no. 5, pp. 711-724, 1993.

[28] J. R. Petherbridge, P. W. May, D. E. Shallcross et al., "Simulation of HCS containing gas mixtures relevant to diamond chemical vapour deposition," Diamond and Related Materials, vol. 12, no. 12, pp. 2178-2185, 2003.

[29] M. A. Mueller, R. A. Yetter, and F. L. Dryer, "Kinetic modeling of the $\mathrm{CO} / \mathrm{H}_{2} \mathrm{O} / \mathrm{O}_{2} / \mathrm{NO} / \mathrm{SO}_{2}$ system: implications for highpressure fall-off in the $\mathrm{SO}_{2}+\mathrm{O}(+\mathrm{M})=\mathrm{SO}_{3}(+\mathrm{M})$ reaction," International Journal of Chemical Kinetics, vol. 32, no. 6, pp. 317-339, 2000.

[30] P. Dagaut, F. Lecomte, J. Mieritz, and P. Glarborg, "Experimental and kinetic modeling study of the effect of $\mathrm{NO}$ and $\mathrm{SO}_{2}$ on the oxidation of $\mathrm{CO} \mathrm{H}_{2}$ mixtures," International Journal of Chemical Kinetics, vol. 35, no. 11, pp. 564-575, 2003.

[31] J. Warnatz, "Hydrocarbon oxidation high-temperature chemistry," Pure and Applied Chemistry, vol. 72, no. 11, pp. 2101-2110, 2000.

[32] C. K. Westbrook and F. L. Dryer, "Chemical kinetic modeling of hydrocarbon combustion," Progress in Energy and Combustion Science, vol. 10, no. 1, pp. 1-57, 1984.

[33] S. Pierucci, E. Ranzi, and L. Molinari, "Modeling a claus process reaction furnace via a radical kinetic scheme," Computer Aided Chemical Engineering, vol. 18, no. 04, pp. 463-468, 2004. 